\title{
Border Control and the Right to Liberty in the Pact: A False Promise of 'Certainty, Clarity and Decent Conditions'?
}

\author{
Galina Cornelisse"
}

\section{Introduction}

When presenting the new Pact on Migration and Asylum in September 2020, the Commission wrote that its underlying rationale is the need for a new, durable European framework: 'one that can provide certainty, clarity and decent conditions for the men, women and children arriving in the EU.' ${ }^{1}$ Particularly when it comes to the detention and accommodation of migrants at the borders of Europe, the last ten years have shown structural weaknesses in EU law and its implementation, precisely with regard to 'certainty, clarity and decent conditions.' Thus, certainty and clarity are negated by the numerous instances of de facto detention that occur at the borders of Europe, ${ }^{2}$ or the vague legal framework governing the situation in the hotspots. ${ }^{3}$ What's more, the conditions that prevail in some of Europe's immigration detention centres, or in other places where people are deprived of their liberty or where their freedom of movement is restricted, are a far cry from any possible interpretation of the term decency. ${ }^{4}$ Thus,

Associate Professor at the University of Amsterdam.

1 Communication from the Commission to the European Parliament, the Council, the European Economic and Social Committee and the Committee of the Regions on a New Pact on Migration and Asylum, $\operatorname{COM}(2020) 609,1$.

2 European Parliament Research Service, 'Asylum Procedures at the Border. European Implementation Assessment' (PE 654.201, November 2020); Galina Cornelisse and Marcelle Reneman, 'Border procedures in the Commission's New Pact on Migration and Asylum: A case of politics outplaying rationality?' (2021) 26 European Law Journal 181-198; and Gruša Matevžič, 'Crossing a Red Line, How EU Countries Undermine the Right to Liberty by Expanding the Use of Detention of Asylum Seekers upon Entry: Case Studies on Bulgaria, Greece, Hungary, and Italy' (Hungarian Helsinki Committee, 2019).

3 Izabella Majcher, 'The EU Hotspot Approach: Blurred Lines between Restriction on and Deprivation of Liberty' (Border Criminologies, 5 April 2018) <https://ssrn.co $\mathrm{m} / \mathrm{abstract}=3204379>$ accessed 5 December 2021.

4 Fundamental Rights Agency, 'Update of the 2016 Opinion of the European Union Agency for Fundamental Rights on fundamental rights in the "hotspots" set up 
proposals for new laws and policies that aim to enhance certainty, clarity and decent conditions in this area are long overdue.

In this contribution I discuss those elements of the New Pact and its accompanying legislative and non-legislative initiatives that touch on detention and freedom of movement of third-country nationals. After setting out the content of the proposals in some detail (Section 2), I investigate these through the lens of fundamental rights compliance (Section 3). I argue that the proposals do not sufficiently contemplate the implications of the link between border control and the liberty of individuals. The absence of a thorough and well-thought-out legal framework regulating detention and freedom of movement at the borders of Europe means that the promise of certainty, clarity and decent conditions can only be translated in practice if substantial changes to the proposed legislation are made, some of which I flesh out in the conclusions to this contribution (Section 4).

\section{Detention, Freedom of Movement and the Pact: An Overview}

Whereas before 2011, EU law had not harmonised the use of detention in the context of migration and asylum procedures, ${ }^{5}$ currently the majority of instruments that form part of the common framework regulating asylum and migration policy contain provisions on detention, a development which is deepened in the Pact. In this section, I provide a brief overview of the instruments included in the Pact that, if adopted, would have an impact on practices of detention or restrictions on liberty. I discuss the new instruments presented in September 2020 together with the earlier proposals for a recast of the Return Directive ${ }^{6}$ and for a recast of the Asylum Reception Conditions Directive ${ }^{7}$, because the Commission foresees the adoption of these latter instruments as part of the Pact.

in Greece and Italy' (February 2019); and Alberto Barbieri, 'Time to rethink large refugee centres in Europe' (2021) 6 The Lancet Public Health.

5 CJEU, Arslan, Case C-534/11, ECLI:EU:C:2013:343.

6 Commission Proposal for a Directive of the European Parliament and the Council on common standards and procedures in Member States for returning illegally staying third-country nationals (recast), $\operatorname{COM}(2018) 634$ final of 12 September 2018 ('Proposal for a recast Return Directive').

7 Proposal for a Directive of the European Parliament and the Council laying down standards for the reception of applicants for international protection (recast), $\operatorname{COM}(2016) 465$ final of 13 July 2016. 


\section{a) Screening}

In the first place, the Commission proposes new migration management tools at external borders which include harmonised procedures to decide swiftly upon arrival. Thus, a "pre-entry phase" is established consisting of a screening and a border procedure for asylum and return, ${ }^{8}$ all of which have implications for the personal liberty of migrants. The screening procedure, in which migrants who do not satisfy the conditions for entry in the Schengen Borders Code, will be registered and screened to establish their identity and to carry out health and security checks, may take up to five days. In exceptional circumstances, this period may be extended by another five days. ${ }^{9}$

The Proposal for a Screening Regulation itself is opaque with regard to the question whether screening at the external border requires detention, although the Commission also writes elsewhere that 'during the screening, migrants would be held by competent national authorities.' ${ }^{10}$. The Proposal, however, 'leaves the determination in which situations the screening requires detention and the modalities thereof [...] to national law.' ${ }^{11}$ It is nonetheless made clear that Member States are 'required to apply measures pursuant to national law to prevent the persons concerned from entering the territory during the screening', which 'in individual cases may include detention'. ${ }^{12}$ Article 3 of the Proposal explicitly obliges Member States to make sure that during the screening, persons 'shall not be authorised to enter the territory of a Member State'.

8 Commission Staff Working Document, Accompanying the document Proposal for a Regulation of the European Parliament and of the Council on asylum and migration management and amending Council Directive (EC)2003/109 and the proposed Regulation (EU)XXX/XXX [Asylum and Migration Fund], SWD(2020) 207 final, 72.

9 Art 6(3) of Commission Proposal for a Regulation of the European Parliament and of the Council introducing a screening of third country nationals at the external borders and amending Regulations (EC) No 767/2008, (EU) 2017/2226, (EU) 2018/1240 and (EU) 2019/817, COM(2020) 612 ('Proposal for a Screening Regulation'). To what extent the screening procedure is a redecoration of existing practices is discussed by Lyra Jakulevičiene in this volume.

10 Commission Staff Working Document, SWD(2020) 207 final, 71.

11 See the Explanatory Memorandum to the Proposal for a Screening Regulation (n 9), 9.

12 See Recital 12 of the Proposal for a Screening Regulation (n 9). 


\section{b) Asylum Border Procedure}

On the basis of the screening, the third-country nationals will be referred to the suitable procedure, which can be an asylum procedure or a return procedure, or a mere refusal of entry. ${ }^{13}$ If persons are channelled in the asylum procedure, their asylum applications will be assessed either in a normal procedure or in a border procedure. The border procedure provides Member States with the possibility (and in some cases the obligation) to examine 'asylum claims with low chances of being accepted rapidly without requiring legal entry to the Member State's territory.' ${ }^{14}$ Hence, one of the defining characteristics of a border procedure is that the applicant is not (yet) authorised to enter the Member State's territory. In this respect the proposed border procedure is similar to the current border procedure in Article 43 of the Asylum Procedures Directive 2013/33 now in force. ${ }^{15}$ The new Article 41(6) in the Amended Proposal for an Asylum Procedures Regulation makes explicit that 'applicants subject to the asylum border procedure shall not be authorised to enter the Member State's territory'. ${ }^{16}$ The border procedure should be as short as possible but no longer than 12 weeks. After that period of time, applicants have a right to enter the territory. ${ }^{17}$ More specifically with regard to the location of the border procedure, the Commission writes that it 'would be more flexible than it currently is, allowing for the holding of applicants not only at the border or in proximity to the border, but also at other locations, should capacity become stretched.' 18

However, just as with regard to the screening procedure, it is not unequivocally clear how the refusal of entry of applicants relates to their right to personal liberty. According to Recital 40f in the Amended Proposal for

13 Commission Communication on a New Pact on Migration and Asylum, $\operatorname{COM}(2020) 609,4$.

14 European Commission, 'New Pact on Migration and Asylum - Building on the progress made since 2016: Questions and Answers' (23 September 2020) <https:/ /ec.europa.eu/commission/presscorner/detail/en/qanda_20_1723> accessed 1 December 2021.

15 Directive 2013/32/EU of the European Parliament and of the Council of 26 June 2013 on common procedures for granting and withdrawing international protection, OJ L 180, 29 June 2013.

16 Amended Proposal for a Regulation of the European Union and of the Council establishing a common procedure for international protection in the Union and repealing Directive 2013/32/EU, COM(2020)611, 14.

17 Ibid, art 41.

18 Staff Working Document, SWD(2020) 207 final, 72. 
an Asylum Procedures Regulation, 'the border procedure for the examination of an application for international protection can be applied without recourse to detention.' Nevertheless, the Recital continues: 'Member States should be able to apply the grounds for detention during the border procedure in accordance with the Reception Conditions Directive.' Whereas the use of detention during the screening phase is thus left to national law, it is to be regulated by EU law during the border procedure: Article 8 under $\mathrm{d}$ of the Proposal for a recast of the Reception Conditions Directive provides for detention in order to decide in the context of a border procedure on the applicants right to enter the territory. ${ }^{19}$

\section{c) Return Border Procedures}

If an asylum border procedure is used and the application is rejected, a return border procedure will follow. The Commission presents the joint asylum and return border procedure as an important migration management tool to prevent unauthorised movements. ${ }^{20}$ The return border procedure is detailed in the same legislative instrument as the asylum border procedure, namely in the amended Proposal for an Asylum Procedures Regulation. As such, it replaces the return border procedure that was included in the 2018 proposal for a recast Return Directive. ${ }^{21}$ Once again, the proposal does not provide clarity to what extent such procedures involve restrictions on freedom of movement or deprive returnees of their personal liberty: Article 41a in the Proposal states that persons whose applications are rejected in the asylum border procedure 'shall be kept for a period not exceeding 12 weeks in locations at or in proximity to the external border or transit zones; where a Member State cannot accommodate them in those locations, it can resort to the use of other locations within its territory.'

In spite of the use of the term "kept" in this provision, the Commission reflects neither in the proposed Asylum Procedures Regulation, nor in any other document, systematically on how return border procedures relate to the right to personal liberty of returnees. More specifically, it fails to

19 This ground for detention is also provided for in the legislation currently in force: Directive 2013/33/EU of the European Parliament and of the Council of 26 June 2013 laying down standards for the reception of applicants for international protection, OJ L 180/96, 29 June 2013 ('Reception Conditions Directive 2013/33').

20 Commission Communication on a New Pact on Migration and Asylum, $\operatorname{COM}(2020) 609,4$.

21 See for more on this Madalina Moraru in this volume. 
address the question under which conditions these procedures involve deprivations of liberty. In the Staff Working Document, it merely writes that irregular migrants in a return border procedure would not be subject to detention as a rule. However, when it is necessary to prevent irregular entry, or there is a risk of absconding, of hampering return, or a threat to public order or national security, they may be subject to detention.'22 The Commission thus suggests that a return border procedure is possible without the use of detention.

With regard to the grounds for detention, the proposed Article 41a in the amended proposal for an Asylum Procedures Regulation distinguishes between two groups: those who were detained during the asylum border procedure and those who were not. The former 'may continue to be detained for the purpose of preventing entry into the territory of the Member State, preparing the return or carrying out the removal process'; the latter 'may be detained if there is a risk of absconding within the meaning of the Return Directive, if they avoid or hamper the preparation of return or the removal process or they pose a risk to public policy, public security or national security.' For both groups, detention shall be maintained for as short a period as possible, as long as removal arrangements are in progress and executed with due diligence. The period of detention shall not exceed 12 weeks, a period that needs to be included in the maximum period of detention under the Return Directive 2008/115.

\section{d) Detention in the Recast Return Directive}

This brings us to the proposal for a recast of the Return Directive tabled by the Commission on 12 September 2018. According to the Commission, the proposed recast consists of targeted amendments aimed at maximising the effectiveness of EU return policy, whilst safeguarding the fundamental rights of irregular migrants. ${ }^{23}$ This has resulted in stricter rules on preventing absconding and unauthorised movements, most conspicuously by introducing an extra ground for the detention of irregular migrants: detention is also permissible if 'the third-country national concerned poses a risk to public policy, public security or national security. ${ }^{24}$ Moreover, Member States are obliged to establish a maximum period of detention of

22 Staff Working Document SWD(2020) 207 final, 72.

23 See the explanatory memorandum to the recast Return Directive.

24 Art 18 of the Proposal for a recast Return Directive (n 6). 
at least three months, a change that the Commission justifies by referring to the ineffectiveness of return policies. ${ }^{25}$ Changes have also been proposed with regard to the risk of absconding and the mandatory denial of a period of voluntary return. These also have clear implications for the right to liberty of returnees, but for reasons of scope these will not be fleshed out here. ${ }^{26}$

\section{e) Detention and Freedom of Movement in Asylum and Transfer Procedures}

Additional changes to the legal framework regulating detention and accommodation of applicants for international protection are foreseen in the Proposal for an Asylum and Migration Management Regulation, ${ }^{27}$ replacing the current Dublin Regulation 604/2013.28 Whereas detention on the basis of current law is only permissible if there is a significant risk of absconding, ${ }^{29}$ the Proposal for an Asylum and Migration Management Regulation uses merely 'risk of absconding' in Article 34. Changes are also made to the time limits applicable to the transfer procedures if detention is used - in most cases resulting in stricter time limits for submitting and replying to requests and carrying out transfers. If these time limits are not obeyed, the third country national concerned should be released.

The Commission Proposal for the recast Reception Conditions Directive which was already touched upon above in the context of border procedures also introduces changes regarding the legal framework regu-

25 Ibid, Explanatory Memorandum, page 8.

26 See for more on this: Galina Cornelisse and Madalina Moraru, 'Judicial dialogue about the Return Directive: Which role for courts in an era of executive governance?' (EU Immigration and Asylum Law Blog, 1 September 2020) <https://eumigr ationlawblog.eu/judicial-dialogue-about-the-return-directive-which-role-for-courts -in-an-era-of-executive-governance/> accessed 1 December 2021.

27 Proposal for a Regulation of the European Parliament and the Council on asylum and migration management and amending Council Directive concerning the status of third-country nationals who are long-term residents, $\operatorname{COM}(2020) 610$ ('Proposal for Asylum and Migration Management Regulation').

28 Regulation (EU) No 604/2013 of the European Parliament and of the Council of 26 June 2013 establishing the criteria and mechanisms for determining the Member State responsible for examining an application for international protection lodged in one of the Member States by a third-country national or a stateless person, OJ L 180/31, 29 June 2013.

29 Art 28 Dublin Regulation 604/2013. See also CJEU, Al Chodor, Case C-528/15, ECLI:EU:C:2017:213. 
lating both freedom of movement and detention in the general asylum procedure. Just as in the current Reception Conditions Directive 2013/32, freedom of movement within the territory of the Member State or within an area assigned to them is the general rule. The proposal for the recast however requires Member States to assign a specific place of residence if this is necessary for reasons of public interest or public order, for the swift processing and effective monitoring of the application, for the swift processing and effective monitoring of transfer procedures or in order to effectively prevent the applicant from absconding. ${ }^{30}$

Such necessity may in particular present itself if the applicant did not make an application for international protection in the Member State of first irregular entry or legal entry. The Proposal defines absconding as the action by which an applicant, in order to avoid asylum procedures, either leaves the territory where he or she is obliged to be present or does not remain available to the competent authorities. A risk of absconding is defined as the existence of reasons in an individual case, which are based on objective criteria defined by national law, to believe that an applicant may abscond. ${ }^{31}$ The proposal makes explicit that 'all decisions restricting an applicant's freedom of movement need to be based on the particular situation of the person concerned, taking into account any special reception needs of applicants and the principle of proportionality.' Moreover, 'applicants must be duly informed in writing of such decisions and of the consequences of non-compliance. ${ }^{32}$

The importance that the Commission attaches to measures restricting freedom of movement is reflected in the fact that an additional ground for detention has been added in Article 8 of the proposed recast: if an applicant has been assigned a specific place of residence but has not complied with the obligation to reside there and there is a continued risk that the applicant will abscond, the applicant may be detained in order to make sure the obligation to reside in a specific place is complied with. This is only possible if the applicant was aware of the obligation and the consequences of non-compliance. The length of the detention must be proportionate and detention is no longer permissible if there are no longer reasons for believing that the applicant will not fulfil the obligation to reside in a particular place. ${ }^{33}$ All the requirements for lawful detention and

30 Proposal for a recast Reception Conditions Directive (n 7), art 7.

31 Ibid, art 2.

32 Ibid, Explanatory Memorandum, page 13.

33 Ibid, page 10. 
applicable guarantees as laid down in the current Reception Conditions Directive 2013/33 remain unchanged.

\section{f) Derogation in Times of Crisis}

The Proposal for a Migration and Asylum Crisis Regulation ${ }^{34}$ concerns provisions adapting the new migration management tools at the border in exceptional situations, some of which have repercussions for the right to liberty. Thus, in the case that a mass influx of irregular arrivals would overwhelm a Member State's asylum, reception or return systems and thus jeopardise the functioning of the CEAS, derogations are allowed from the proposed Asylum Procedures Regulation, making it possible to extend the duration of the asylum border procedure and the return border procedure with another 8 weeks. ${ }^{35}$ The preamble of the Proposal for a Migration and Asylum Crisis Regulation clarifies that it should be possible to use detention during this period as well, in accordance with Article 41a of the Proposed Procedures Regulation when it concerns the return border procedure (and presumably on the basis of the recast Reception Conditions Directive in cases of the asylum border procedure). Moreover, the Crisis instrument introduces two cases, additional to the ones set in the proposal for a recast Return Directive, in which the existence of a risk of absconding in individual cases can be presumed, unless proven otherwise. Such a presumption may subsequently provide the basis for using detention on the basis of Article 18 of the proposed recast of the Return Directive. The two additional grounds are (1) explicit expression of intent of non-compliance with return-related measures, or (2) when the applicant, third-country national or stateless person concerned is manifestly and persistently not fulfilling the obligation to cooperate. ${ }^{36}$

Also significant in the context of crisis management is the Migration Preparedness and Crisis Blueprint, ${ }^{37}$ which is not a legislative instrument but a recommendation by the Commission on an EU mechanism for

34 Proposal for a Regulation of the European Parliament and of the Council addressing situations of crisis and force majeure in the field of migration and asylum, $\operatorname{COM}(2020) 613$.

35 Proposal for a Migration and Asylum Crisis Regulation, art 4 and 5.

36 Ibid.

37 Commission Recommendation (EU) 2020/1366 of 23 September 2020 on an EU mechanism for Preparedness and Management of Crises related to Migration ('Migration Preparedness and Crisis Blueprint'), C(2020) 6469, OJ L 317/36. 
'Preparedness and Management of Crises related to Migration'. Although the recommendation does not explicitly mention detention or accommodation, some of its aspects reflect the current operational coordination in the hotspots between Member States and the EU and its agencies, such as EASO, Frontex and Eurojust. Indeed, the Blueprint aims to consolidate the operational cooperation developed so far, by establishing a framework which supports a more coordinated use of the relevant legislation in order to avoid crisis situations such as in 2015 and to ensure the effective functioning of national migration systems. It provides for two stages in such coordination: the preparedness stage and the crisis stage.

The toolbox for the crisis stage, provided in the Annex to the Recommendation, provides several measures to be taken at external borders. Most relevant for accommodation and detention are the following measures: 'Hotspots and reception centres are established at the points of high pressure staffed by relevant national authorities and supported by the EU Agencies with the necessary migration and security information systems. ${ }^{3} 3$ The Commission also 'deploys staff to Member States at the EU external borders to assist in the coordination of the response actions.' Moreover, 'EASO deploys, in coordination with Member States, relevant staff and equipment to assist on reception and asylum', and 'Europol deploys, in coordination with Member States, [...] officers to perform security checks of arriving migrants. ${ }^{39}$ Frontex is also given a role in the toolbox 'by deploying return specialists and by organising and coordinating return operations by charter and scheduled flights including with return escorts and return monitors. ${ }^{40}$ The mobilisation of EASO, Frontex, and Europol to work together with the authorities of frontline Member States in the hotspot approach 'to help to fulfil their obligations under EU law and swiftly identify, register and fingerprint incoming migrants' was first put forward in the 2015 European Agenda on Migration, ${ }^{41}$ and further developed in the Regulation on the European Border and Coast Guard. ${ }^{42}$

38 Ibid, 36.

39 Ibid.

40 Ibid.

41 Communication from the Commission to the European Parliament, the Council, the European Economic and Social Committee and the Committee of the Regions, A European Agenda on Migration, COM(2015)240 final, 4.

42 Regulation of the European Parliament and of the Council of 13 November 2019 on the European Border and Coast Guard and repealing Regulations (EU) No 1052/2013 and (EU) 2016/1624, OJ L 295/1. 


\section{Fundamental Rights Compliance}

With regard to all proposed measures discussed above, the Commission pays some attention to compliance with the right to liberty and freedom of movement. For example, the Explanatory Memorandum to the Crisis Regulation states that these rights are 'protected given that, if detention is used in the context of the derogatory rules to the asylum and return border procedure, such derogatory rules can only be applied in a strictly regulated framework and for a limited time. ${ }^{43}$ In a similar fashion, the Commission writes with regard to the proposal for a recast of the Reception Conditions Directive that it is 'fully compatible with Article 6 of the EU Charter of Fundamental Rights, read in the light of Article 5 of the European Convention on Human Rights and relevant jurisprudence of the Court of Justice of the European Union and the European Court of Human Rights. ${ }^{44}$ And the Staff Working Document underlines that detention in the return border procedure 'could be used only in individual cases, as a last resort (no effective alternatives available), for the shortest possible period of time and provided that procedures by national authorities are conducted with due diligence, and in any case not exceeding the maximum duration of the border procedure (12 weeks for asylum, 12 weeks for return). ${ }^{45}$ It is striking however, that in the Staff Working Document, the relatively brief section on reinforcing migrants and asylum seekers' rights unapologetically presents measures that do not even come close to reinforcing rights, but instead restrict them. ${ }^{46}$ Thus, it is acknowledged that the refusal of entry to the territory inherent to a border procedure has an impact on the right to liberty, but is nevertheless 'necessary to discourage applicants with abusive claims to enter the Union without a valid reason. ${ }^{47}$

\section{a) Containment at External Borders and De Facto Detention}

When it comes to compliance with the right to personal liberty, perhaps the most striking trait of the Pact is the implicit blurring of the lines

43 Proposal for a Migration and Asylum Crisis Regulation, 12.

44 Proposal for a recast Reception Conditions Directive (n 7), Explanatory Memorandum.

45 Staff Working Document SWD(2020) 207 final, 85.

46 Section 5.5. of Staff Working Document SWD(2020) 207 final, on a 'fairer and more effective system to reinforce migrants and asylum seekers' rights'.

47 Ibid. 
between detention and restrictions on freedom of movement, a tendency that is arguably typical for contemporary migration governance and that has been highlighted by scholars calling attention to containment practices beyond the premises of detention sites. ${ }^{48}$ The most pertinent question raised by such practices is to what extent our current fundamental rights framework is capable of addressing the resulting challenges. Screening and border procedures are characterised by the refusal of entry. At the same time, applicants for international protection have a right to remain under EU law and they cannot be returned before the existence of a risk of refoulement is assessed. ${ }^{49}$ Moreover, Article 18 of the Charter provides for the right to asylum. This particular construction inevitably impacts on the liberty of applicants who apply for asylum at the border or in a transit zone. Indeed, in these procedures, entry is refused precisely in order to prevent free movement within the territory of the Member State (and potential subsequent irregular movements across the EU).

To what extent policies of non-entry at the external border as foreseen in the screening and border procedures (both asylum and return) interfere with the right to personal liberty raises complex issues of fact and law questions the answers to which, as we have seen over the past few years, may vary depending on which court in Europe answers them. ${ }^{50}$ The particular legal constellation of EU law is such that in most cases, the "holding" of applicants for asylum at the border or in transit zones before entry is granted, will amount to deprivation of liberty, and not as mere restrictions on freedom of movement. ${ }^{51}$ In this context, it is worth highlighting that

48 Martina Tazzioli and Glenda Garelli, 'Containment beyond detention: The hotspot system and disrupted migration movements across Europe’ (2020) 38(6) Environment and Planning D: Society and Space.

49 CJEU, Gnandi, Case C-181/16, ECLI:EU:C:2018:465. See also art 9 of Reception Conditions Directive 2013/33 (n 19).

50 Thus, containment of applicants for asylum in the Röszke transit area was deemed to constitute detention by the Court of Justice in FMS, Case C-924/19, ECLI:EU:C:2020:367 and Commission v Hungary, Case C-808/18, ECLI:EU:C:2020:1029 whereas such containment under almost comparable circumstances in Ilias and Ahmed was not qualified as such by the Grand Chamber of the ECtHR (Ilias and Ahmed $v$ Hungary App no 47287/15, ECtHR, 21 November 2019).

51 Galina Cornelisse, 'Borders, Procedures and Rights at Röszke: Reflections on Case C-924/19 (PPU)' (European Database of Asylum Law, April 2020) <www.asyluml awdatabase.eu/en/journal/borders-procedures-and-rights-röszke-reflections-c ase-c-92419-ppu> accessed 1 December 2021; and Galina Cornelisse, 'Territory, Procedures and Rights: Border Procedures in European Asylum Law' (2016) 35 (1) Refugee Survey Quarterly 74-90. See also Galina Cornelisse and Marcelle 
in 2013, the Commission was of the opinion that border procedures could 'be used only in exceptional circumstances, since they imply detention.' 52 Moreover, in the Explanatory Memorandum of the 2016 Proposal for the APR, the Commission also wrote that border procedures 'normally imply the use of detention throughout the procedure'. ${ }^{53}$ There is no justification in the Pact for the change of position on such a crucial aspect of the proposed Asylum Procedures Regulation, which now maintains that asylum border procedures for the can be applied without recourse to detention. ${ }^{54}$

Addressing all the intricacies of the legal qualification of a stay at the border or in the transit zone would go beyond the scope of this contribution. ${ }^{55}$ For now it suffices to highlight that the CJEU has defined detention in this particular policy context as 'a coercive measure that deprives [an] applicant of his or her freedom of movement by requiring him or her to remain permanently within a restricted and closed perimeter.' 56 The possibility to leave this area will not call into question the assessment of a situation as detention, if this is not a legal possibility or results in forfeiting the right to asylum. ${ }^{57}$

Reneman, 'Legal assessment of the implementation of Article 43 of Directive 2013/32/EU on common procedures for granting and withdrawing international protection' (European Parliament Research Service, PE 654.201, November 2020).

52 Communication from the Commission to the European Parliament pursuant to Article 294(6) of the Treaty on the Functioning of the European Union concerning the position of the Council on the adoption of a proposal for a Directive of the European Parliament and of the Council on common procedures for granting and withdrawing international protection, $\operatorname{COM}(2013) 411$ final, 4.

53 Explanatory Memorandum to the Proposal for a Regulation of the European Parliament and of the Council establishing a common procedure for international protection in the Union and repealing Directive 2013/32/EU COM(2016) 467 final, 15.

54 It is likely that political, not legal, reasons are behind this change, as border procedures in particular were one of the stumbling blocks in reaching political agreement over the 2016 Proposal for the APR. See Council of the European Union, 'Note from the Presidency to: Strategic Committee on Immigration, Frontiers and Asylum (SCIFA)', 13376/18, LIMITE, 19 October 2018.

55 This issue is delved out in detail, including the way in which such containment relates to the 1951 Refugee Convention, in the legal study underlying the European implementation assessment of border procedures in the EU. Cornelisse and Reneman, 'Legal assessment of the implementation of Article 43 of Directive 2013/32/EU on common procedures for granting and withdrawing international protection' (n 51).

56 CJEU, FMS, Case C-924/19, ECLI:EU:C:2020:367 and Commission v Hungary, Case C-808/18, ECLI:EU:C:2020:1029.

57 See also Opinion of AG in CJEU, FMS, Case C-924/19, ECLI:EU:C:2020:294. 
At the same time, it is well known that in human rights law, the distinction between a deprivation of liberty (detention) and a restriction on freedom of movement is one of 'degree or intensity and not one of nature or substance. ${ }^{58}$ Nonetheless, once a situation is qualified as detention, a number of safeguards kick in. Most notably is the habeas corpus guarantee, giving the detainee the right to have the lawfulness of the detention speedily reviewed by a court and to have the detention lifted if it is unlawful. ${ }^{59}$ Although safeguards are not absent in EU law when it concerns restrictions on freedom of movement, they are less robust. Article 7 of the proposal for the recast Reception Conditions Directive requires that 'measures restricting freedom of movement are proportionate and based on the individual behaviour and particular situation of the person concerned.' Moreover, such measures, provided that they 'affect applicants individually' should ultimately be the subject of 'an appeal, in fact and in law, before a judicial authority.' Even leaving aside the question what is meant with the qualification that measures should 'affect applicants individually' to merit judicial review, the scope, intensity and possible outcomes of such review, as well as the speed with which it should be carried out, are entirely left to national law.

Lesser procedural protection when freedom of movement of applicants is restricted to a particular area, for example in cases of a particular geographical restriction, ${ }^{60}$ makes sense in many cases, especially when compared to a full-blown detention regime in an immigration detention centre. The problem is however, that precisely with regard to practices of containment at the border, the difference between detention and restrictions on freedom of movement can be difficult to draw. The result is that practices that are qualified as detention by one Member State, may not be seen as such by another. ${ }^{61}$ This jeopardises the uniformity of EU law, seeing that applicants in similar situations have different procedural protection at their disposal: for example, judicial review of the lawfulness of a deprivation of liberty is not enjoyed uniformly by individuals across

58 Guzzardi v Italy App no 7367/76 (ECtHR, 6 November 1980).

59 Art 5(4) ECHR and see also CJEU, Mahdi, Case C-146/14 PPU, ECLI:EU:C:2014:1320

60 Alexandra Bousiou, 'From Humanitarian Crisis Management to Prison Island: Implementing the European Asylum Regime at the Border Island of Lesvos 2015-2017' (2020) 22 (3) Journal of Balkan and Near Eastern Studies 431-447.

61 Cornelisse and Reneman, 'Legal assessment of the implementation of Article 43 of Directive 2013/32/EU on common procedures for granting and withdrawing international protection' (n 51). 
the EU. More fundamentally, also under the current legal framework, the complexity surrounding the stay of third-country nationals at borders or in transit zones results in numerous instances of de facto detention in Europe, be it at border posts, transit zones, reception centres, boats, islands or airports. ${ }^{62}$

The proposals in the Pact do not in any way address this problem, which may partly be due to the fact that the transposition of current EU law has not been evaluated by the Commission. Presenting the screening and border procedures as a panacea for problems encountered at external borders therefore raises more questions than it answers. The asylum and return border procedures as proposed in the Asylum Procedures Regulation will inevitably augment existing problems in this field. Moreover, the proposal for the Screening Regulation, by leaving it entirely up to national law whether or not to use detention during the screening phase, flaunts a complete ignorance of the challenges encountered at the borders of Europe when it comes to respecting the fundamental rights of migrants. By not addressing these in a sustained manner, the Pact cannot be said to bring about certainty and clarity for the men, women and children arriving in the EU. As regards decent conditions: the last years have shown that conditions of detention at the border or in transit zones raise particular problems and it is not clear how the Commission envisages addressing these.

\section{b) Accommodation at the Borders and Hotspots: A "System to Match the Scale of the Challenge"?}

The Commission portrays the will to make the New Pact a reality as 'the only way to prevent the recurrence of events such as those seen in Moria [...]: by putting into place a system to match the scale of the challenge. ${ }^{63}$ Statements such as these seem incongruous when we consider that the 'more efficient, seamless and harmonised migration management system' 64 as proposed in the Pact largely replicates the modus operandi as currently employed at the hotspots; albeit without introducing clear measures to

62 Matevžič (n 2).

63 Commission Communication on a New Pact on Migration and Asylum, $\operatorname{COM}(2020) 609$.

64 Staff Working document, $\operatorname{SWD}(2020) 207$ final, 70. 
prevent well-documented violations of human rights. ${ }^{65}$ Thus, the current hotspots are places where migrants are screened and then channeled in the proper procedures. This channeling, minus the operational coordination and support (which is foreseen in times of crisis in the Blueprint) is precisely what the Commission proposes to do now at all external borders. The Pact in its current form actually promotes the model of large hosting centres at the external borders of the European Union. ${ }^{66}$ The dangers that accommodation in these types of centres pose for the physical and mental health of migrants are well documented ${ }^{67}$ and it remains unclear how the Commission envisages countering these risks.

Moreover, as mentioned above, it is remarkable that it does not pay structural attention to the way in which these policies relate to detention, except from heedless statements, such as irregular migrants in a return border procedure would not be subject to detention as a rule. ${ }^{98}$ Now, how does that rule relate to the obligation by Member States to keep returnees from entering the territory if their return cannot be arranged yet? And what are the prospects for proper implementation of that rule considering the complete lack of evaluation of current practices? For example, in Greece, under the fast track border procedure at the Aegean islands, appellants whose appeals are rejected 'are immediately detained upon the notification of the second instance negative decision. ${ }^{69}$ With regard to Italy, the CPT has reported that migrants who did not express the intention to apply for international protection 'and against whom a refusal of entry (rejection) order or a removal order had been issued, could remain in the 'hotspots' for days or even weeks, and potentially until their forced return or transfer to a CPR, without any judicial control. ${ }^{30}$ How such

65 Fundamental Rights Agency, 'Update of the 2016 Opinion of the European Union Agency for Fundamental Rights on fundamental rights in the 'hotspots' set up in Greece and Italy' (February 2019).

66 Ecorys in collaboration with Galina Cornelisse and Giuseppe Campesi, 'The European Commission's New Pact on Migration and Asylum: European Substitute Impact Assessment (European Parliament Research Service, PE 694.210, August 2021).

67 Barbieri (n 4).

68 Staff Working Document, SWD(2020) 207 final, 73.

69 Greek Council for Refugees, 'Country Report: Fast-track border procedure (Eastern Aegean islands)' (AIDA Database, 10 June 2021).

70 Council of Europe, Report to the Italian Government on the visit to Italy carried out by the European Committee for the Prevention of Torture and Inhuman or Degrading Treatment or Punishment (CPT/Inf (2018), 7 to 13 June 2017), 13 and 16. 
problems can be prevented from occurring in the future is not discussed by the Commission, not even when presenting the extension of periods allowed for screening and border procedures in times of crisis, as foreseen in the Crisis Regulation. Moreover, how the Pact envisages to improve the living conditions in the hotspots remains unclear.

The current framework undergirding the hotspot approach seems to be replicated in the proposals in another way as well: the extra ground for detention in the proposal for the recast Reception Conditions Directive as discussed above mirrors practice in Greece, where applicants for asylum who violated the geographical restriction applied to them are upon arrest transported back to the Islands and detained (albeit without a legal basis in Greek law). ${ }^{71}$ In a similar fashion, the added grounds for assigning applicants for asylum a specific place of residence in Article 7 of the Reception Conditions Directive reflect current practice at the hotspots.

\section{Conclusions}

If the EU genuinely wishes to set up a 'system to meet the scale of the challenge', ${ }^{72}$ more sustained reflection is needed on the way in which the proposed, novel instruments of migration management pose challenges to the effective protection of fundamental rights. No-one can be unaware of the systematic infringements of the right to liberty and substandard living conditions suffered by those held at the borders of Europe. A policy that fails to engage sincerely with the question how to prevent these violations from occurring in the future cannot be taken seriously. Without having carried out a proper evaluation of the current instruments employed at the borders of Europe, the Commission presents the new migration management tools as a solution. This, together with the fact that it failed to produce an impact assessment of the proposals and the Pact as a whole, is in contradiction with its own Better Regulation guidelines. ${ }^{73}$ The absence of an impact assessment is particularly striking seeing the potentially se-

71 Greek Council for Refugees, 'Country Report: Greece' (AIDA Database, 31 December 2018).

72 Commission Communication on a New Pact on Migration and Asylum, $\operatorname{COM}(2020) 609,28$.

73 Commission Staff Working Document, Better Regulation Guidelines, SWD (2017) 350. See also Cornelisse and Reneman, 'Border procedures in the Commission's New Pact on Migration and Asylum: A case of politics outplaying rationality?' (n 2). 
rious effects on fundamental rights of migrants, a few of which I have highlighted in this contribution. In the substitute impact assessment that was carried out by the EPRS in 2021, the negative impact of pre-entry procedures in particular on the right to liberty was clearly illustrated. ${ }^{74}$ In this respect, it is significant that in the recent draft report by the LIBE Rapporteur on the Proposal for a Screening Regulation, key amendments are proposed, such as the removal of the fiction of non-entry. ${ }^{75}$ More generally, when it comes to the negotiations of the Pact, the implementation of a legal concept of non-entry into the territory and the systematic use of detention as well as possible alternatives to it, remain a topic of intense political disagreement, also within the Council. ${ }^{76}$ It is not a topic which is about to decrease in political or humanitarian salience; quite the contrary, as is shown by the current developments at Eastern external borders. ${ }^{77}$

The question that lingers after a thorough examination of those elements of the Pact that have repercussions for the right to liberty: for what precisely does the Proposal provide a solution? For it contains disappointingly little - if any - answers for the men, women and children who are detained at the borders of Europe without a formal detention order or under conditions that cannot be described as decent by any stretch of the imagination, nor for those who dwell in the hotspots after they have been formally released from detention but 'still trapped under conditions highly similar to those of detention. ${ }^{78}$ The Pact contains surprisingly little elaboration to the guarantees that are traditionally the most pertinent when it comes to fundamental rights protection: judicial remedies. Such remedies should be taken onboard in the proposed legislation, with specific regard

74 Ecorys in collaboration with Cornelisse and Campesi (n 66).

75 Committee on Civil Liberties, Justice and Home Affairs, Draft Report on the proposal for a regulation of the European Parliament and of the Council introducing a screening of third-country nationals at the external borders and amending Regulations (EC) No 767/2008, (EU) 2017/2226, (EU) 2018/1240 and (EU) 2019/817 (COM(2020) 612), 15 November 2021.

76 Presidency, Pact on Migration and Asylum - Progress Report, Council Document 8540/21, LIMITE, 24 May 2021.

77 See R.A. and Others $v$ Poland App no 42120/21 (ECtHR, 28 August 2021); and H.M.M. and Others v. Latvia App no 42165/21 (ECtHR, 25 August 2021) on interim measures for persons refused entry at the external borders of Poland and Lithuania.

78 Spyros-Vlad Oikonomo and the Greek Council of Refugees, 'Borderlines of Despair: First-line reception of asylum seekers at the Greek borders' (25 May 2018), 21. 
to the complexities that are introduced when the lines between restrictions on freedom of movement and deprivation of liberty are blurred.

This can be done for example by ensuring that, when Member States employ policies of non-entry, a decision in writing should qualify the measures preventing entry as either detention or restrictions on freedom of movement. The decision should moreover provide reasons in fact and law, not only for the restriction itself but also for its qualification. In addition, both detention and restrictions on freedom of movement, if these are decided by an administrative authority, should be subject to a speedy judicial review, and the scope of such review should be such as to enable the judicial authority to substitute its own decision for that of the administrative authority with regard to the qualification of the measure. Additionally, the judicial authority should be able to take into account any element that it considers necessary for assessing the lawfulness of the restricting measures, including its conditions. ${ }^{79}$ Seeing that the rule of law and the protection of individual rights in the EU largely depends on a 'decentralised judicial architecture', ${ }^{80}$ robust judicial remedies before national judges are called for in order to ensure that the desired "clarity, certainty and decent conditions" do not remain an empty promise.

79 Cornelisse and Reneman, 'Legal assessment of the implementation of Article 43 of Directive 2013/32/EU on common procedures for granting and withdrawing international protection' ( $\mathrm{n}$ 51); and Cornelisse and Reneman, 'Border procedures in the Commission's New Pact on Migration and Asylum: A case of politics outplaying rationality?' (n 2).

80 Volker Roeben, 'Judicial Protection as the Meta-norm in the EU Judicial Architecture' (2020) 12 Hague Journal on the Rule of Law (2020) 29-62. 
